\title{
INTRA-OPERATIVE FINDINGS OF ATTICO-ANTRAL TYPE OF CHRONIC SUPPURATIVE OTITIS MEDIA: A STUDY OF 85 PATIENTS.
}

\footnotetext{
1. MBBS, FCPS, DLO Professor ENT

Faisalabad Medical University, Faisalabad.

2. MBBS, FCPS

Senior Registrar ENT Allied Hospital Faisalabad.

3. MBBS

House Officer

Allied Hospital Faisalabad.
}

Correspondence Address:

Dr. Naeem Akhtar

Department of ENT

Faisalabad Medical University,

Faisalabad.

drnaeem.ent@gmail.com

Article received on:

08/02/2020

Accepted for publication:

$15 / 05 / 2020$

\begin{abstract}
Naeem Akhtar ${ }^{1}$, Muhammad Waqas ${ }^{2}$, Asma Naeem ${ }^{3}$
ABSTRACT... Objectives: Chronic suppurative otitis media is the most common ear disease in Otolaryngology OPD and Head \& Neck surgery in tertiary care hospitals worldwide. Due to its life threatening complications and management difficulties, attico-antral disease, a type of CSOM poses a huge challenge to otolaryngologists. Study Design: Descriptive study. Setting: Department of Otolaryngology and Head \& Neck Surgery Allied Hospital (FMU) Faisalabad. Period: From January 2016 to December 2018. Material \& Methods: Eighty five patients with CSOM of attico-antral type were included. Results: Forty six patients $(54.1 \%)$ were male and thirty nine patients (45.9\%) were female, aged 07 to 58 years with an average age of 23.7 years. 42 patients $(49.4 \%)$ had a right ear disease and 43 patients $(50.6 \%)$ had a left ear disease. Granulation tissue was observed in 50 patients $(58.8 \%)$, cholesteatoma in 27 patients $(31.7 \%)$ and both granulation tissue and cholesteatoma in 08 patients (09.5\%). The main pathology was observed to involve the attic area only of 04 patients $(04.7 \%)$, attic and middle ear of 44 patients $(51.7 \%)$, attic and antrum of 16 patients $(18.9 \%)$ and attic, middle ear, antrum and other mastoid air cells in 21 cases (24.7\%). The malleus handle was found eroded in 10 patients $(11.8 \%)$, head \& handle in only 02 patients (02.4\%). In 23 patients (27\%) long process of incus was damaged while incus was completely eroded in 03 patients (03.5\%). The suprastructure of stapes was found eroded in 03 patients (03.5\%). Conclusion: Granulation tissue is the most common primary lesion along with cholesteatoma associated with attico-antral type of CSOM. Due to this pathology, the incus is the most frequently eroded small bone of the middle ear. In addition the management of granulation tissue and cholesteatoma poses a huge challenge to the otolaryngologists. Therefore, the general practitioners are needed to be educated for early referral to otolaryngologist for early and rapid management to prevent complications due to attico-antral type of CSOM.
\end{abstract}

Key words: Atticoantral Disease, Chronic Suppurative Otitis Media, Cholesteatoma, Canal Wall Down Mastoidectomy, Granulation Tissue.

Article Citation: Akhtar N, Waqas M, Naeem A. Intra-operative findings of attico-antral type of chronic suppurative otitis media: A study of 85 patients. Professional Med J 2020; 27(10):2229-2234. DOI: 10.29309/TPMJ/2020.27.10.4556

\section{INTRODUCTION}

Chronic suppurative otitis media (CSOM) is a common public health problem worldwide especially in developing countries. ${ }^{1}$ Atticoantral disease, a type of CSOM, is characterized by the development of granulation tissue, cholesteatoma or both, which constitutes an Otolaryngologist a huge challenge because of its potential complications. Chronic suppurative otitis media (CSOM) can be defined as a longterm inflammation involving some or all of the middle ear cleft lasting more than three months, characterized by ear leaks and permanent perforation of the tympanic membrane. ${ }^{2}$ However, there is no consensus on symptoms duration. According to World Health Organization CSOM is called chronic when the ear drum perforation is for at least two weeks. ${ }^{3}$ Other otologists define CSOM as chronic if the ear discharge lasts longerthan six weeks. ${ }^{4}$

Clinically CSOM is divided into two types namely: tubotympanic and attico-antral type of CSOM. The tubotympanic disease involves anteroinferior part of the middle ear cleft (Eustachian tube and mesotympanum) and is associated with a central perforation in the tympanic membrane. This variety is also known as safe or benign 
type of CSOM as there is no risk of serious complications. ${ }^{5}$ On the other hand attico-antral type of CSOM involves posterosuperior part of the middle ear cleft (Attic, aditus, antrum and other mastoid cells) and is characterized by an attic or marginal perforation of the ear drum. It is often associated with bone erosion process such as granulation tissue, cholesteatoma or osteitis, which can be prone tohigh risk of complications. This is why this variety is also known as unsafe or dangerous type of CSOM. ${ }^{6}$ There is another classification of CSOM in the literature: Mucosal disease and squamosal disease. The mucosal disease is further subdivided into: i. Active chronic supportive otitis media (perforation of ear drum with ear leaks), ii. Inactive with permanent dry perforation, and iii. Healed otitis media characterized by permanent abnormalities of pars tensa and no retraction of pars tensa or flaccida. The Squamousal disease is divided into: i. Retraction pockets in pars tensa or pars flaccida (also known as atelectasis of ear), and ii. Active squamosal disease characterized by cholesteatoma with ear secretions. ${ }^{7}$

Cholesteatoma is a benign keratinized epithelial cell structure that occurs in the middle ear and mastoid. It may be congenital or acquired. Congenital cholesteatoma originates from the cell rests of embryonic epithelial cells. The term 'Cholesteatoma' was first used by a German physiologist Johannes Muller in $1838 .{ }^{8}$ Atticoantral CSOM can sometimes be associated with dangerous complications. These complications are mainly caused by granulation tissue and cholesteatoma due to bone erosion and necrosis. In this way important structures of the middle ear cleft such as facial nerve, inner ear, small ear bones and even intracranial components may be damaged. ${ }^{9}$ Non-cholesteatoma CSOM rarely occurs in which ossicular erosion may occur, and is attributed to cytokines such as Tumour necrosis factor- alpha, interleukin-2, fibroblast growth factor, and platelet derived growth factor. These in turn promote angiogenesis, osteoclast activation and bone resorption leading to bone damage. ${ }^{10}$

Early detection and timely treatment of CSOM in rural and illiterate patients can prevent life threatening complications and reduce morbidity. Ears containing relatively large amount of cholesteatoma and granulation tissue require more urgent surgical treatment and broader disease clearance to prevent complications. ${ }^{2}$ There are many surgical procedures to manage granulation tissue and cholesteatoma of the middle ear cleft, such as atticotomy, radical mastoidectomy and modified radical mastoidectomy. The main purpose of our study was to identify the main pathology, namely, granulation tissue, cholesteatoma or both, to what extent and the ossicular damage caused by it.

\section{MATERIAL \& METHODS}

This retrospective interventional descriptive study was conducted during the period from January 2016 to December 2018 in the department of Otolaryngology and Head \& Neck surgery allied hospital (FMU) Faisalabad. 85 patients with attico-antral type of CSOM with or without complications, of either gender, ranging from 07 to 58 years and giving consent for mastoid exploration were included in the study. Patients under 07years and over 58 years, with acute suppurative otitis media, binaural disease and patients who were unwilling to undergo mastoid exploration were excluded from the study.

All patients were asked in details according to a printed form. Detailed history regarding ear discharge, hearing loss, fever, ear ache, headache, nausea, vomiting, tinnitus, dizziness and upper respiratory tract infection was documented. A comprehensive physical examination of all the patients was undertaken including otology, ear otoscopy, ear examination under the operating microscope, general physical examination and examination of respiratory and central nervous systems. Appropriate investigations including $\mathrm{CBC}$, urine tests, blood urea, sugar, ear discharge for culture \& sensitivity, x-rays mastoid and CT scan of mastoid temporal bones were asked from all the patients of the study.

In addition all the patients also underwent pure tone audiometry and tympanometry. Moreover, x-rays 
PNS, x-rays chest, ECG and echocardiography were also required in certain selected candidates to rule out any contraindication to surgical intervention. All the data was analyzed by using appropriate statistics. Analysis using Chi square test was performed and a ' $p$ ' value less than 0.05 was considered as significant.

\section{RESULTS}

In this study of 85 patients, 46 patients (54.1\%) were male and 39 patients (45.9\%) were female (Figure-1), aged 07 to 58 years, with an average age of 23.7 years (Table-I). 42 patients (49.4\%) had right ear disease and 43 patients (50.6\%) had left ear disease (Figure-2). 50 patients (58.8\%) were found to have granulation tissue, 27 patients (31.7\%) developed cholesteatoma and 08 patients (09.5\%) developed both granulation tissue and cholesteatoma (Figure-3). The main pathology was observed to involve the attic area in only 04 patients $(04.7 \%)$, attic and middle ear of 44 patients $(51.7 \%)$, and the attic and antrum of 16 patients (18.9\%). Twenty one patients $(24.7 \%)$ were enrolled to have the main pathology in the attic, middle ear, antrum and other mastoid air cells. (Table-II). 10 patients (11.8\%) were found to have erosion of malleus handle, only 02 patients $(02.4 \%)$ had erosion of head, while intact malleus was found in 73 patients (85.8\%). In 23 patients $(27 \%)$, long process of incus was seen eroded and 03 patients $(03.5 \%)$ had complete erosion of incus. Suprastructure of stapes was found absent in $03(03.5 \%)$ patients (Table-III). There were no complications in 59 patients (69.4\%) and 26 patients (30.6\%) presented with complications (Table-IV).

\begin{tabular}{|c|c|c|c|}
\hline $\begin{array}{c}\text { Serial } \\
\text { Number }\end{array}$ & Age Range & $\begin{array}{c}\text { No. of } \\
\text { Patients }\end{array}$ & Percentage \\
\hline 1 & $7-10$ years & 05 & $05.9 \%$ \\
\hline 2 & $11-20$ years & 31 & $36.5 \%$ \\
\hline 3 & $21-30$ years & 31 & $36.5 \%$ \\
\hline 4 & $31-40$ years & 13 & $15.3 \%$ \\
\hline 5 & $41-50$ years & 04 & $04.7 \%$ \\
\hline 6 & $51-58$ years & 01 & $01.1 \%$ \\
\hline Total & & 85 & $100 \%$ \\
\hline
\end{tabular}

Table-I. Age Distribution showing that majority i.e; 62 patients $(73 \%)$ fall within the age range of $11-30$ years.

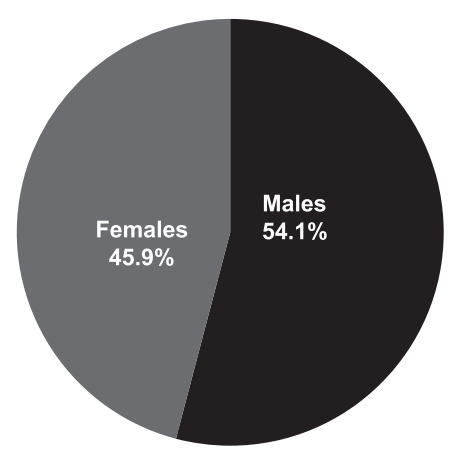

Figure-1. Sex distribution

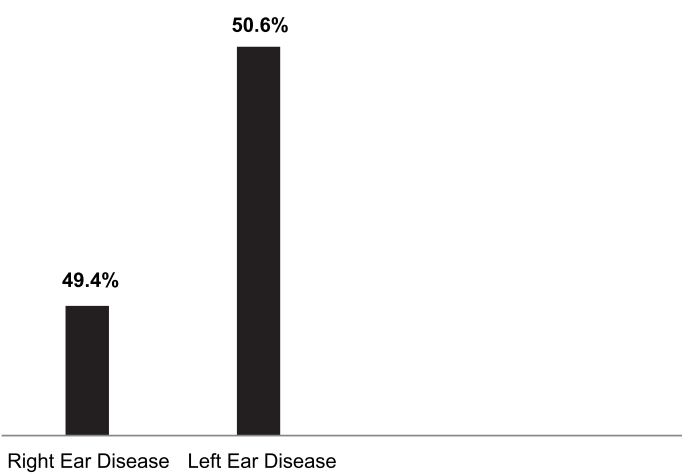

Figure-2. Ear affected

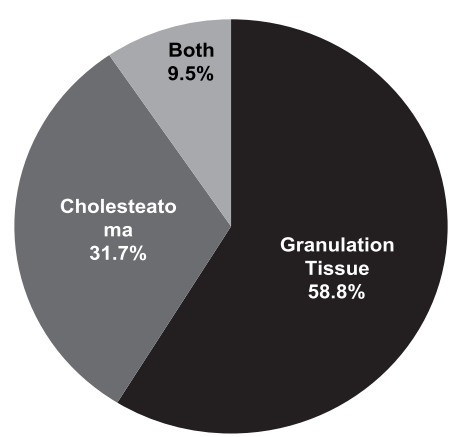

Figure-3. Primary pathology in attico-antral type of CSOM

\begin{tabular}{|c|c|c|c|}
\hline $\begin{array}{c}\text { Serial } \\
\text { Number }\end{array}$ & Region/Site & $\begin{array}{c}\text { No. of } \\
\text { Patients }\end{array}$ & Percentage \\
\hline 1 & Attic & 04 & $04.7 \%$ \\
\hline 2 & Attic \& Middle Ear & 44 & $51.7 \%$ \\
\hline 3 & Attic and Antrum & 16 & $18.9 \%$ \\
\hline 4 & $\begin{array}{c}\text { Attic, Middle Ear, } \\
\text { Antrum \& Other } \\
\text { Mastoid Cells }\end{array}$ & 21 & $24.7 \%$ \\
\hline Total & & 85 & $100 \%$ \\
\hline
\end{tabular}

Table-Il. Extent of the primary pathology. 


\begin{tabular}{|c|c|c|c|c|}
\hline Serial Number & Ossicle & Extent of Erosion & No. of Patients & Percentage \\
\hline 1 & Malleus & $\begin{array}{l}\text { 1.Erosion of Handle } \\
\text { 2.Erosion of Head \& Handle } \\
\text { 3.Intact Malleus }\end{array}$ & $\begin{array}{l}10 \\
02 \\
73\end{array}$ & $\begin{array}{l}11.8 \% \\
02.4 \% \\
85.8 \%\end{array}$ \\
\hline 2 & Incus & $\begin{array}{l}\text { 1.Erosion of long process } \\
\text { 2.Complete erosion } \\
\text { 3.Intact Incus }\end{array}$ & $\begin{array}{l}23 \\
03 \\
59\end{array}$ & $\begin{array}{l}27.0 \% \\
03.5 \% \\
69.5 \%\end{array}$ \\
\hline 3 & Stapes & $\begin{array}{l}\text { 1.Erosion of suprastructure } \\
\text { 2.Intact Stapes }\end{array}$ & $\begin{array}{l}03 \\
82\end{array}$ & $\begin{array}{l}03.5 \% \\
96.5 \%\end{array}$ \\
\hline
\end{tabular}

Table-III. Ossicular status during mastoid exploration

\begin{tabular}{|c|c|c|c|c|}
\hline Serial Number & & Name of Complication & No. of Patients & Percentage \\
\hline \multirow[t]{2}{*}{1} & $\begin{array}{l}\text { Atticoantral disease } \\
\text { with complications }\end{array}$ & $\begin{array}{l}\text { 1.Mastoid Abscess } \\
\text { 2.Brain Abscess } \\
\text { 3.Facial Palsy } \\
\text { 4.Mastoid Fistula } \\
\text { 5.Aural Polyp }\end{array}$ & $\begin{array}{l}04 \\
05 \\
03 \\
02 \\
12\end{array}$ & $\begin{array}{l}04.8 \% \\
05.9 \% \\
03.5 \% \\
02.3 \% \\
14.1 \%\end{array}$ \\
\hline & Total & & 26 & $30.6 \%$ \\
\hline \multirow[t]{2}{*}{2} & $\begin{array}{l}\text { Atticoantral disease } \\
\text { without complication }\end{array}$ & No complication & 59 & $69.4 \%$ \\
\hline & Grand total & & 85 & $100 \%$ \\
\hline
\end{tabular}

Table-IV. Atticoantral type of CSOM with Complications

\section{DISCUSSION}

Chronic supportive otitis media (CSOM) is a global public health problem, especially in the developing countries. ${ }^{1}$ This disease poses a huge challenge to the otolaryngologists because of its potential complications, especially due to its dangerous variety named attico-antral disease.

Our research work showed that males $(54.1 \%)$ predominated over the females (45.9\%). This maledominance model is prevalent throughout the world. ${ }^{9,11}$ However, studies by Agrawal et al ${ }^{12}$ and Balasubramanian et $\mathrm{al}^{13}$ reveal a pattern of female predominance. Our study also showed that the young active age group (11-30 years old) was the most affected (73\%). Similar results can be seen in studies conducted by Agrawal et $\mathrm{al}^{12}$ and Jamro et al. ${ }^{14}$ The main reason for this age group being affected by this disease may be the fact that this is the most active and healthconscious age group.

Compared with right ear (49.4\%) in our series, the left ear was found to be affected slightly higher $(50.6 \%)$. Similar pattern is also seen in the study conducted by Balasubramanian et al. ${ }^{13}$

Granulation tissue was the most common pathological lesionin our patients (58.8\%), followed by cholesteatoma (31.7\%) and 08 patients (09.5\%) were found to have both granulation tissue and cholesteatoma. Some national and international studies also indicate the granulation tissue to be the most frequent pathology followed by cholesteatoma involving the middle ear cleft. ${ }^{12,14,15}$ However, most international studies have shown that cholesteatoma is the most common pathology followed by granulation tissue in the middle ear cleft. ${ }^{16,17}$

During mastoid exploration our attic and middle ear were mostly affected by the primary disease $(51.7 \%)$ i.e; granulation tissue, cholesteatoma or both. The attic, middle ear and mastoid were affected in $24.7 \%$, attic and mastoid antrum in $18.9 \%$ and attic was found to be involved in only $04.7 \%$ of our series. According to Jamro et $\mathrm{al}^{14}$, the involvement rate of attic area alone is $05 \%$, the occupancy rate in the attic and middle ear is $37.5 \%$, the involvement rate of the attic and mastoid antrum is $20 \%$, and the attic, middle ear, antrum and other mastoid air cells are involved by the pathology in $37.5 \%$. A research done by Shrestha et $\mathrm{al}^{17}$ showed that $82 \%$ of the patients had involvement of attic, middle ear and mastoid by the primary disease. 
Intra-operative findings of the ossicular status in our study reveal that ossicular erosion was seen in $48.2 \%$ of the cases while $51.8 \%$ patients had intact ossicles. Moreover, this study also showed that incus was the most commonly erodedossicle by the disease (30.5\%). The malleus was eroded in $14.2 \%$ patients whereas stapes was eroded in only $03.5 \%$ of the patients. These findings of our research work closely match the findings obtained by Balasubramanian et al. ${ }^{13}$ However, other international studies show higher incidence of ossicular erosion as shown by studies conducted by Shrestha et $\mathrm{al}^{16}$ and Thapa et al. ${ }^{18}$ According to another study conducted by Chao WY and Wu $\mathrm{CC}^{19}$ in the past, the erosion of ossicles was seen in $35.4 \%$ of the cases.

All the patients with attico-antral disease in this study were managed surgically by performing canal wall down procedures either modified radical mastoidectomy or radical mastoidectomy along with Tympanoplasty type III.

\section{CONCLUSION}

The granulation tissue is the most frequent pathology found in the attico-antral type of CSOM and incus is the ossicle most commonly eroded by the disease. Furthermore, the management of granulation tissue poses a great challenge to the otolaryngologists due to its recurrence character. Majority of these patients present themselves primarily to a general practitioner. Therefore, education of general practitioners is an important step towards timely referral to ENT specialist for correct and early management. In addition, awareness program among the general public regarding the disease is need of the hour for early intervention to prevent dangerous complications attributed to attico-antral disease.

Copyright@ 15 May, 2020.

\section{REFERENCES}

1. Muftah S, Mackenzie I, Faragher B and Brabim B. Prevalence of chronic suppurative otitis media (CSOM) and associated hearing impairment among school-aged children in Yemen. Oman Med J. 2015; 30 (5): 358-365.
2. Vikram BK, Khaja N, Udayashankar SG et al. Clincoepidemiological study of complicated and uncomplicated chronic suppurative otitis media. The Journal of Laryngology and Otology. 2008; 122: 442446.

3. Acuin J. World health organization. Chronic suppurative otitis media: Burden of illness and management options. Geneva, Switzerland: World Health Organization; 2004.

4. Acuin J. Chronic suppurative otitis media. BMJ Clin Evid. 2007; 02: 507.

5. Kingsnorth A, Bowlet D, Editors. Fundamentals of head and neck surgery. In: fundamentals of surgical practice. $3^{\text {rd }}$ Edition. New york: Cambridge University Press; 2011; 308.

6. Harkness P, Topham J. Classification of otitis media. Laryngoscope.1998; 108:1539-1593.

7. Browning GG, Weir J, Kelly G and Swan IRC. Chronic otitis media. Scott-Brown's otorhinolaryngology and head and neck surgery: Vol.2: Paediatrics, The Ear and Skull base. $8^{\text {th }}$ Edition, 977-983. CRC Press; 2018.

8. Muller J. Uber den feinerenBau und die Formender krankhaften Geschwulste. Reimer: Berlin; 1838.

9. Rout MR, Mohanty D, Vijaylaxmi Y, Kamalesh B, Chakradher M. Prevalence of cholesteatoma in chronic suppurative otitis media with central perforation. Indian J Otol. 2012; 18: 7-10.

10. Varshney S,Nangia A,Bist SS, Singh RK, Gupta $\mathrm{N}$, Bhagat $\mathrm{S}$. Ossicular chain status in chronic suppurative otitis media in adults. Indian j Otolaryngol Head Neck Surg. 2010; 62: 421-6.

11. Kaur N, Sharma DK, Singh J. Clinico-social profile of patients of atticoantral disease in middle ear cleft attending tertiary care center of North India. Int $\mathrm{J}$ Ad Med. 2016; 3 (3): 737-743.

12. Agrawal N, Sharma HsS, Raghuvanshi V et al. Incidence of CSOM unsafe type in rural population of central India. JMSCR.2017; 5 (2): 17690-17694.

13. Balasubramanian C, Santhanakrishna Kumar B, Anandan $\mathrm{H}$. A study on ossicular erosion in chronic suppurative otitis media. Int J Sci St. 2017; 5 (5): 9497.

14. JamroBU, Magsi PB, Sangi HA. Intra operative findings during canal wall down mastoidectomy in chronic suppurative otitis media at a tertiary care hospital, Sukhur, Pakistan. Rawal Med J. 2013; 38 (2): 173-176. 
15. Udaipurwalal $H$, lqbal $K$, Saqlain $G$, Jalisi $M$. Pathological profile in chronic suppurative otitis media; The regional experiences. J Pak Med Assoc. 1994; 44: 235-7.

16. Shrestha D, Thapa P, Bhandari VB. Types of pathology and ossicular status in atticoantral disease undergoing mastoidectomy at Bir Hospital. JColl Med Scien, Nepal. 2010; 6 (4); 26-30.
17. Shrestha S, Kafle P. Intra-operative findings during canal wall down mastoidectomy in children. J Nepal Paediatric Soc. 2011; 31: 184-7.

18. Thapa NM, Bhattarai H, Amatya RCM. Types of pathology and ossicular status in atticoantral disease undergoing mastoid exploration at TUTH. J. Inst. Med. 2001; 24: 3-4.

19. Chao WY and Wu CC. Hearing impairment in chronic suppurative otitis media with cholesteatoma. j. Formos Med Assoc.1994; 93: 866-9.

\begin{tabular}{|c|c|c|c|}
\hline \multicolumn{4}{|c|}{ AUTHORSHIP AND CONTRIBUTION DECLARATION } \\
\hline Sr. \# & Author(s) Full Name & Contribution to the paper & Author(s) Signature \\
\hline 1 & Naeem Akhtar & $\begin{array}{l}\text { Main author, Manuscript } \\
\text { writing. }\end{array}$ & \\
\hline 2 & Muhammad Waqas & Statistics. & \\
\hline 3 & Asma Naeem & $\begin{array}{l}\text { Data collection \& proof } \\
\text { reading. }\end{array}$ & " \\
\hline
\end{tabular}

